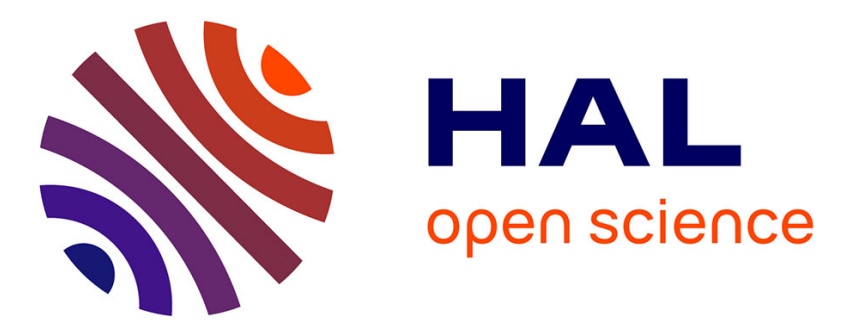

\title{
Differences in physiological response to increased seawater temperature in nearshore and offshore corals in northern Vietnam
}

Suzanne Faxneld, Tove Lund Jörgensen, Ngai D. Nguyen, Magnus Nyström, Michael Tedengren

\section{To cite this version:}

Suzanne Faxneld, Tove Lund Jörgensen, Ngai D. Nguyen, Magnus Nyström, Michael Tedengren. Differences in physiological response to increased seawater temperature in nearshore and offshore corals in northern Vietnam. Marine Environmental Research, 2011, 71 (3), pp.225. 10.1016/j.marenvres.2011.01.007 . hal-00673200

\section{HAL Id: hal-00673200 https://hal.science/hal-00673200}

Submitted on 23 Feb 2012

HAL is a multi-disciplinary open access archive for the deposit and dissemination of scientific research documents, whether they are published or not. The documents may come from teaching and research institutions in France or abroad, or from public or private research centers.
L'archive ouverte pluridisciplinaire HAL, est destinée au dépôt et à la diffusion de documents scientifiques de niveau recherche, publiés ou non, émanant des établissements d'enseignement et de recherche français ou étrangers, des laboratoires publics ou privés. 


\section{Accepted Manuscript}

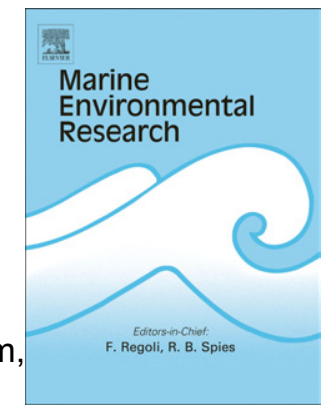

Title: Differences in physiological response to increased seawater temperature in nearshore and offshore corals in northern Vietnam

Authors: Suzanne Faxneld, Tove Lund Jörgensen, Ngai D. Nguyen, Magnus Nyström Michael Tedengren

PII: S0141-1136(11)00018-3

DOI: 10.1016/j.marenvres.2011.01.007

Reference: MERE 3503

To appear in: Marine Environmental Research

Received Date: 6 January 2011

Accepted Date: 24 January 2011

Please cite this article as: Faxneld, S., Jörgensen, T.L., Nguyen, N.D., Nyström, M., Tedengren, $M$. Differences in physiological response to increased seawater temperature in nearshore and offshore corals in northern Vietnam, Marine Environmental Research (2011), doi: 10.1016/ j.marenvres.2011.01.007

This is a PDF file of an unedited manuscript that has been accepted for publication. As a service to our customers we are providing this early version of the manuscript. The manuscript will undergo copyediting, typesetting, and review of the resulting proof before it is published in its final form. Please note that during the production process errors may be discovered which could affect the content, and all legal disclaimers that apply to the journal pertain. 


\section{Differences in physiological response to increased seawater temperature in nearshore and offshore corals in northern}

\section{Vietnam}

Suzanne Faxneld $^{\mathrm{a}^{*}}$, Tove Lund Jörgensen ${ }^{\mathrm{a}}$, Ngai D. Nguyen ${ }^{\mathrm{c}}$, Magnus Nyström ${ }^{\mathrm{a}, \mathrm{b}}$, Michael Tedengren ${ }^{\mathrm{a}}$

a) Department of Systems Ecology, Stockholm University, SE-106 91 Stockholm, Sweden

b) Stockholm Resilience Centre, SE-106 91 Stockholm, Sweden

c) Institute of Marine Environment and Resources, 246 Da Nang Street, Hai Phong City, Vietnam

* Corresponding author. Department of Systems Ecology, Stockholm University, SE-106

91 Stockholm, Sweden. E-mail: suzanne@ecology.su.se, phone: +46 (0) 8 164277, fax: +46 (0) 8158417 


\section{ABSTRACT}

2 Effects of elevated seawater temperature show high spatial heterogeneity and variation

3 within and among coral species. The objective of this study was to investigate how two

4 coral species, Porites lutea and Galaxea fascicularis, from two high latitude reefs

5 differently exposed to chronic disturbance, respond to elevated seawater temperatures.

6 Corals were collected from reefs nearshore, (i.e. subjected to high sediment load, higher

7 chlorophyll $\alpha$ concentrations, turbidity etc.) and offshore, (i.e. less exposed). The corals

8 were exposed in the lab to gradually increasing temperatures $\left(25.5-33.5{ }^{\circ} \mathrm{C}\right)$ for $72 \mathrm{~h}$

9 after which they were allowed to recover to ambient temperature $\left(25.5^{\circ} \mathrm{C}\right)$ for $24 \mathrm{~h}$.

10 Production and respiration were measured after 24, 48, 72 and 96 hours. The results show

11 that $P$. lutea from nearshore reefs suffered an initial decrease in gross primary

12 production/respiration (GP/R) ratio after $24 \mathrm{~h}$, after only a moderate temperature increase

$13\left(+2{ }^{\circ} \mathrm{C}\right.$, from 25.5 to $\left.27.5^{\circ} \mathrm{C}\right)$, while there was no difference in GP/R ratio between heat-

14 exposed and controls the other days, indicating that the chronic disturbance in the

15 nearshore reef had no effect on their thermotolerance. Furthermore, P. lutea from the

16 offshore reef showed a decrease in GP/R ratio both after $24 \mathrm{~h}$ and $72 \mathrm{~h}\left(33.5^{\circ} \mathrm{C}\right)$ of

17 exposure.

18 In comparison, G. fascicularis showed a decrease in GP/R ratio after 48 h, $72 \mathrm{~h}$ and $96 \mathrm{~h}$

19 of exposure for the nearshore corals. Also, after $72 \mathrm{~h}$ these corals had withdrawn their

20 polyps. There were no differences between heat-treated and controls for the offshore $G$.

21 fascicularis. This implies that the chronically disturbed G. fascicularis had lower

22 thermotolerance when exposed to a temperature increase. 
23 This study, hence, shows that the response of corals to elevated seawater

24 temperature varies with species and environmental background history.

26 Keywords: Increased water temperature, Galaxea fascicularis, Porites lutea, Disturbance,

27 Physiological responses, High latitude reefs, Vietnam

28

29 


\section{Introduction}

32 Coral reefs have shown a remarkable persistence, despite reoccurring natural disturbance

33 events (Wood, 1995). However, reef-building corals have a very restricted thermal

34 tolerance (Hoegh-Guldberg, 1999). If temperature exceeds a given thermal limit corals

35 may lose their colour, i.e. they "bleach". This decolouration is due to the expulsion of the

36 endosymbiotic microalgae (zooxanthellae) found in the polyp tissue, making the white

37 calcium carbonate skeleton underneath visible (Douglas, 2003). Since corals receive up to

$3895 \%$ of their energy from their zooxanthellae via photosynthesis (Muscatine, 1990)

39 bleaching may cause significant mortality, unless the coral host is repopulated with

40 symbionts, in due time (species specific) to allow recovery (Glynn, 1996; Diaz-Pulido

41 and McCook, 2002). Hence, in the face of climatic changes and increased sea surface

42 temperatures (IPCC, 2007) there is great concern for the future health of coral reefs

43 (Hughes et al., 2003; Sheppard and Rioja-Nieto, 2005; Hoegh-Guldberg et al., 2007). In

44 tandem coral reefs are exposed to direct human impacts, such as increased sedimentation,

45 increased nutrient loading, pollution etc., which may reduce their capacity to respond to

46 environmental changes caused by changes in climate.

$47 \quad$ Extensive coral mortality due to climate-induced bleaching events (i.e. mass coral

48 bleaching) has occurred repeatedly over the past decades across all oceans (Wilkinson,

49 2006). These events are predicted to increase in frequency and magnitude in the future

50 (Hoegh-Guldberg, 1999; Donner et al., 2005). The observed patterns of bleaching,

51 however, show great spatial variability (e.g. McClanahan et al., 2007). A multitude of

52 variables may explain different thermal tolerances, including coral morphology 
53 (McClanahan, 2000; Spencer et al., 2000; Edwards et al., 2001), taxa (McClanahan,

54 2004; McClanahan et al., 2004; Ulstrup et al., 2006), depth (Brown, 1997; Warner et al.,

55 1999; Spencer et al., 2000; Craig et al., 2001), distribution of zooxanthellae clades (i.e.

56 genotypes) (Glynn et al., 2001; Baker et al., 2004; Rowan, 2004), and local temperature

57 variations due to local current regimes (McClanahan et al., 2005). Furthermore, it has

58 also been suggested that reduced water quality can amplify the impacts of elevated

59 seawater temperature (Hughes et al., 2003; Pandolfi et al., 2007; Mora, 2008). For

60 example, experimental studies suggest that thermal tolerance in corals can be reduced by

61 exposure to heavy metals (Nyström et al., 2001), increased nutrients (Nordemar et al.,

62 2003) sedimentation (Lambo and Ormond, 2006) and decreased salinity (Faxneld et al.,

63 2010).

64 Besides climate change, increase in sediment load due to human activities, is

65 considered a major threat to coral reefs (Bryant et al., 1998; Hughes et al., 2003;

66 Wilkinson, 2004). Sedimentation can lead to reduced coral species diversity and

67 increased mortality, reduced calcification- and growth rates, decreased net production and

68 increased respiration (Rogers, 1990; Crabbe, 2005; Fabricius, 2005; Jupiter et al., 2008).

69 Approximately $50 \%$ of the reefs in Vietnam are threatened by sedimentation

70 (Burke et al., 2002). Tuan (2000) reported that the proportion of reefs with less than 25\%

71 live coral cover increased from $25 \%$ before 1998 to $50 \%$ of the reefs by 1999 in the

72 Halong Bay and Cat Ba Island (the study area). This has mainly been attributed to

73 sedimentation (Chou et al., 2002). During that time, Acropora spp. suffered significant

74 mortality on many reefs while Galaxea fascicularis was basically unaffected. In 2002 G.

75 fascicularis was still the dominating species on many reefs in Halong Bay with up to $40 \%$ 
76 of the benthic cover (Nguyen D Ngai unpubl. data), thus indicating that tolerance to

77 sedimentation varies among coral species.

78 The aim of this study was to investigate potential differences in physiological

79 responses to elevated temperature depending on exposure to earlier disturbance regimes.

80 For this purpose two common coral species, Porites lutea and Galaxea fascicularis were

81 used. Corals were collected from two nearshore reefs, more exposed to sedimentation,

82 high chlorophyll $\alpha$ concentrations and nutrients etc. (Fig. 2a and Table 1) and two

83 offshore (less disturbed) reefs (Fig.1). Two opposite outcomes were predicted

84 beforehand: (1) corals exposed to chronic disturbance will have reduced capacity to

85 withstand further thermal stress, since these corals may already be close to their

86 physiological tolerance limit or (2) corals exposed to chronic disturbance will have

87 enhanced capacity to withstand further stress, due to a more developed acclimatory

88 ability.

89 Differences in physiological responses within and between species from different

90 disturbance regimes can be relevant for identifying sensitive and tolerant coral species

91 when exposed to additional stress and may have implications when deciding future

92 establishment of marine protected areas.

93

94 2. Material and methods

95

96 2.1. Study area

97

98

Halong Bay 
99 Halong Bay is a relatively shallow turbid bay exposed to high nutrient loading (Latypov,

100 2005). Most coral reefs in Halong Bay are also affected by sedimentation and coastal

101 pollution, especially nearshore reefs (Lang et al., 2004). Furthermore, shipping in and out

102 of the bay stirs up the sediments from the bottom thus affecting the reefs, more so in the

103 nearshore sites (Tran et al., 2004). Due to the high turbidity in the bay corals are

104 restricted to shallow waters and their maximum depth distribution is limited to $3-4 \mathrm{~m}$ on

105 nearshore- and to 5-7 $\mathrm{m}$ on offshore reefs (Lang et al., 2004). Water temperature

106 fluctuates dramatically over the year with a winter (December-February) minimum of 16

$107{ }^{\circ} \mathrm{C}$ and normal summer (June-August) maximum around $31.5^{\circ} \mathrm{C}$. Halong Bay is a

108 relatively species-poor coral community, and it is dominated by massive coral species,

109 such as Galaxea fascicularis and Porites lutea. Branching genera, such as Acropora and

110 Pocillopora are relatively scarce (Latypov, 2005; Nguyen D Ngai unpubl.).

\section{2.2. Collection of corals}

114 Pieces of corals were collected at 2-3 m depth from two reef areas in May 2007 (Fig. 1).

115 The disturbed (i.e. nearshore) reef area (Cat Ba Island National Park) (including site A

116 and B) is situated close to the coast, in a semi-enclosed area with limited water exchange

117 and receives run-off water from several rivers, whereas the offshore area (Long Chau

118 Islands) (including site $\mathrm{C}$ and $\mathrm{D}$ ) is located approximately $20 \mathrm{~km}$ south of the nearshore

119 reef area. The latter location is an open area with good water exchange and it is less

120 affected by land run-off water (e.g. less sediments, nutrients and lower chlorophyll $\alpha$

121 concentrations (a proxy for water clarity, see LaJeunesse et al., 2010a and 2010b). 
122 Although several environmental parameters differ between the near- and offshore area,

123 temperature and salinity regimes were almost identical between the areas throughout the

124 year (see Table 1 and Fig. 2a and 2b); and the ambient temperature and salinity during

125 collection was $25.5^{\circ} \mathrm{C}$ and 32 psu at all sites. Corals from the two reef areas thus have

126 very similar thermal histories. Within each area, two reef sites were sampled. In the

127 nearshore area, Ba Trai Dao Island (site A, N 20 47' 20", E $107^{\circ} 06^{\prime} 1^{\prime \prime}$ ) ) and Van Boi

128 Island (site B, N $20^{\circ} 45^{\prime} 35^{\prime \prime}, \mathrm{E} 107^{\circ} 04^{\prime} 24^{\prime \prime}$ ) were selected and in the offshore area, coral

129 specimens were collected from Vung Cay Bang Island (site C, N 20 37' 27", E 107 09'

$\left.13041^{\prime \prime}\right)$ and Vung Tau Island (site D, N $20^{\circ} 37^{\prime} 21^{\prime \prime}$, E $\left.107^{\circ} 08^{\prime} 08^{\prime \prime}\right)$ (Fig 1). The corals were

131 collected using a hammer and chisel. Two massive species, Porites lutea and Galaxea

132 fascicularis, were selected and at each of the four sites 10 coral pieces (approximately 85

$133 \mathrm{~cm}^{2}$ and $120 \mathrm{~cm}^{2}$ for $P$. lutea and $G$. fascicularis respectively) of each species were

134 collected, except for one nearshore site (Van Boi) where no G. fascicularis and only 6

135 pieces of $P$. lutea could be found. Hence, 36 pieces of $P$. lutea and 30 pieces of $G$.

136 fascicularis were collected in total. Immediately after collection, corals were transported

137 to the outdoor laboratory at the Tram Bien Research Station in Do Son under low light

138 condition and continuous aeration. After epiphytes and boring organisms had been

139 carefully removed, the corals were put in aerated aquaria (20 litre each) with filtered and

140 UV-treated seawater. The aquaria were placed in larger water-filled tanks $\left(1 \mathrm{~m}^{3}\right)$ in order

141 to minimise temperature fluctuations (Nyström et al., 2001; Nordemar et al., 2003). The

142 corals were allowed to acclimate to the set control temperature of $25.5^{\circ} \mathrm{C}$ and $32 \mathrm{psu}$

143 (ambient at site of collection) and thereafter kept at that temperature for $48 \mathrm{~h}$ before the

144 experiment was started. 
148 The corals were evenly distributed in eight 20-litre aquaria using a randomized block

149 design. Four of the aquaria were then placed in a heating tank $\left(1 \mathrm{~m}^{3}\right)$ representing

150 temperature "exposure" and the other four were placed in a control tank $\left(1 \mathrm{~m}^{3}\right)$ with

151 ambient water temperature. Aeration pumps mixed the seawater in both the aquaria and

152 the tanks, thus maintaining high oxygen concentrations and distributing water

153 temperature evenly. The water temperature in the exposure tank was increased using

154 heating regulators (ZEBO $300 \mathrm{~W}$ or FLUVAL Tronic 200W). The temperature was

155 recorded every hour during daytime (between 10 am to $6 \mathrm{pm}$ ) and once in the evening as

156 well as once in the early morning (at $9 \mathrm{pm}$ and 6 am respectively) to verify constant

157 temperature throughout a $24 \mathrm{~h}$ period before the experiment was started. Throughout the

158 experiment, temperature was measured continuously during the physiological

159 measurements. Between measurements, temperatures were recorded every second hour

160 during daytime and once in the evening as well as once in the early morning (at 9 pm and

1616 am respectively). The experiment lasted for $96 \mathrm{~h}$ (4 days) during which the temperature

162 was gradually increased for three days, to mimic a natural gradual temperature increase,

163 and then reduced to ambient for a 24-hour recovery period. It is well known that daily

164 temperatures can undergo drastic changes on nearshore reef flats and in coastal lagoons,

165 e.g. $25-33{ }^{\circ} \mathrm{C}$ within hours (Semesi et al., 2009). Normal summer temperature in Halong

166 Bay is $30-31.5^{\circ} \mathrm{C}$ (Nguyen 2004; Latypov 2005), and studies have shown that large

167 increases $(3-4$ 
$168{ }^{\circ} \mathrm{C}$ above normal summer maximum) over a few days can bleach corals (Glynn and

169 D'Croz 1990; Jokiel and Coles 1990). The temperature treatment in the exposure tank

170 was set to: day $1:\left(27.5^{\circ} \mathrm{C}\right)$, day $2:\left(30.5^{\circ} \mathrm{C}\right)$, day $3:\left(33.5^{\circ} \mathrm{C}\right)$ and day $4:\left(25.5^{\circ} \mathrm{C}\right)$. The

171 maximum exposure temperature of $33.5^{\circ} \mathrm{C}$ in the present study was chosen since $2{ }^{\circ} \mathrm{C}$

172 above expected summer maximum is known to induce physiological stress in most coral

173 species. It took approximately four hours before the new temperature was reached.

174 Hence, the corals were exposed in each temperature for 20 hours before the production

175 and respiration were measured. Temperature in the control tank was maintained at 25.5

$176{ }^{\circ} \mathrm{C}$ throughout the study. Due to effective heaters and stirring we were able to keep the

177 temperatures very constant (deviation $<0.2{ }^{\circ} \mathrm{C}$ from set temperature) throughout the

178 experiment. The experiment was conducted outdoors in natural sunlight, under low light

179 conditions $\left(414-529 \mu \mathrm{E} \mathrm{m}^{-2} \mathrm{~s}^{-1}\right)$, corresponding to recorded light levels on shallow reefs

180 (e.g. Semesi et al., 2009). Production and respiration measurements were conducted each

181 day for both exposed and control corals.

\section{2.4. Physiological measurements}

185 Before net primary production and respiration were measured, each coral was put in a 1.5

186 litre transparent plastic jar with a tight-fitting lid, without extra supplies of oxygen. Each

187 jar contained water with a temperature identical to the treatment temperature. During the 188 measurements, the temperatures also in the measurement jars were constant (set temp. \pm

$1890.2^{\circ} \mathrm{C}$ ). Changes in dissolved oxygen concentration in light (net primary production) and 190 darkness (respiration) were measured according to Moberg et al. (1997) using an 
191 oximeter (WTW OXI 330). An earlier pilot test showed that the most stable and reliable

192 values were obtained after a 30 minutes and 2.5 hours acclimation period in light and

193 darkness for production and respiration, respectively. Dissolved oxygen concentration

194 was initially measured in light and then again after 30 minutes. Corals were then placed

195 in darkness and after $2.5 \mathrm{~h}$ the oxygen concentration was measured once more and

196 respiration rates calculated. Before the statistical analyses, production and respiration

197 rates were converted to 1 -hour values. Four water controls (jars containing only water)

198 were used for each measurement, two with control water temperature and two with a

199 temperature that corresponded to that of the exposed corals. Net primary production was

200 always measured during mid-day, at $1 \mathrm{pm}$. During the measurements, the oxygen

201 saturation levels never dropped below 75\%. To compensate for volume dependent

202 differences in dissolved oxygen concentration, the volumes of the corals were measured

203 by submerging the coral into a graded beaker filled with a known volume of water. Live

204 coral surface area was determined using the aluminium foil method (March, 1970). Net

205 production- and respiration rates were expressed per hour and coral surface area $\left(\mathrm{cm}^{2}\right)$.

206 Respiration rate $(\mathrm{R})$ was added to the net production value in order to achieve gross

207 primary production rate (GP). Gross primary production rates were then corrected for

208 temporal differences in light intensities between measurements. This was done to

209 compensate for light dependent differences between measurements, since measurements

210 were performed for four consecutive days. In order to do this, the production values were

211 divided by the light intensity during measurement, and then multiplied with the average

212 light intensity during all measurements, assuming a linear relationship between light

213 intensity and primary production in the narrow light interval in this study. Due to lack of 
214 laboratory facilities, data on coral biomass, zooxanthellae density and chlorophyll

215 concentration could not be obtained. Consequently gross primary production and

216 respiration rates are expressed as per $\mathrm{cm}^{2}$ coral surface area according to Moberg et al.

217 (1997). Gross primary production/respiration (GP/R) ratios were also calculated to get a

218 dimensionless estimate of the physiological status of the corals.

220 2.5. Statistical analysis

222 A two-way ANOVA was used to analyse the effect of site (i.e. nearshore site A vs. B and

223 offshore site C vs. D) and treatment (i.e. heat vs. control) on the gross primary production

224 rate, respiration rate and GP/R ratio of both species. Since there were no differences

225 between the two offshore or nearshore sites (the data from site A and B, and the data

226 from site C and D) the data were pooled into one offshore and one nearshore group for

227 each species. A General Linear Model (GLM) univariate one-way ANOVA was used to

228 analyse the effects of the four different treatments (i.e. offshore / heat, nearshore / heat,

229 offshore / control and nearshore / control) on gross primary production rate, respiration

230 rate and GP/R ratio for $G$. fascicularis and $P$. lutea respectively. The analyses were

231 carried out separately for each day and species. Where the one-way ANOVA showed

232 differences, Tukey HSD was used as a post hoc test $(\mathrm{p}<0.05)$. All data were tested for

233 homogeneity of variances using Levene's test $(p<0.05)$ before the ANOVA was carried

234 out. When necessary, the data were log transformed. When Levene's test showed

235 differences in variance and no transformations proved efficient, the non-parametric 
236 Kruskal-Wallis and Mann-Whitney $U$ test was used. For the statistical analyses SPSS

$237 \quad 17.0$ for Mac OS X was used.

238

239 3. Results

240

241 3.1. Galaxea fascicularis

242

243 There were significant differences when comparing heat-treated corals and controls in

244 nearshore and offshore areas (Table 2). Corals from the nearshore area showed a

245 significant decrease in GP/R ratio on day 2, 3 and 4 when exposed to elevated

246 temperature compared to the controls ( $\mathrm{p}<0.05$ Tukey HSD, Fig. 3a), whereas no

247 significant differences were observed for heat-treated and controls for the offshore corals

248 (Fig. 3b). The differences in GP/R ratio for the nearshore corals were mainly caused by

249 an increase in respiration rates compared to the control (Table 3a). However, on day 3 the

250 difference was also explained by a decrease in gross primary production rates compared

251 to the control (Table 3b).

252 Sixty percent of the heat-treated Galaxea fascicularis from the nearshore area had

253 withdrawn their polyps (Fig. 4a) after exposure to $33.5^{\circ} \mathrm{C}$, i.e. on the third day of

254 exposure. Heat-treated offshore- and control corals showed no such response (Fig. 4b).

256 3.2. Porites lutea

257 
258 For $P$. lutea there were significant differences between heat-treated and control corals

259 from nearshore and offshore areas (Table 4). The GP/R ratio was significantly lower on

260 day 1 for nearshore heat-treated corals compared to the controls $(\mathrm{p}<0.05$ Tukey HSD,

261 Fig. 5a). This was explained by a significant increase in respiration rates that day ( $\mathrm{p}<$

2620.01 Tukey HSD, Table 5a). Furthermore, the offshore heat-treated corals displayed a

263 significant decrease in GP/R ratio both on day 1 and day 3 ( $p<0.05$ Tukey HSD, Fig.

$2645 b$ ). This decrease in GP/R ratio was mainly explained by an increase in respiration rates

265 (Table 5a). There were no differences in gross primary production rates between

266 treatments (Table 5b).

268 4. Discussion

270 For Galaxea fascicularis the GP/R ratio differed between the offshore and nearshore area,

271 except for day 1. Heat-treated corals from nearshore reefs showed a decrease in GP/R

272 ratio throughout the study. On day 3 the corals had also withdrawn their polyps, which

273 might explain the large decrease in gross primary production rate observed that day. A

274 direct effect on zooxanthellae cannot be excluded although no counting of zooxanthellae

275 could be done. Other studies have shown that withdrawal of polyps is a stress response in

276 corals (Coyer et al., 1993; Brown et al., 1994; Jones et al., 2000).

277 The difference in response between nearshore and offshore G. fascicularis

278 suggests that corals pre-exposed to other stressors (i.e. nearshore corals) are more

279 sensitive to heat stress compared to the offshore (less disturbed) reefs. Similar findings

280 have been reported by Carilli et al. (2009), who investigated skeletal growth rates in

281 Montastrea faveolata before and after the 1998 bleaching event in reefs exposed to 
282 different levels of local stress (e.g. sedimentation and nutrients). The authors found that

283 the growth rate was suppressed for longer time after the bleaching event at the reefs

284 exposed to higher levels of stress, thus they were less resilient to coral bleaching.

285 There were no significant differences in physiological response between Porites

286 lutea from offshore and nearshore reefs on any day of exposure (Fig. 5a and 5b). There

287 were only significant differences between heat-treated and control corals for the

288 nearshore $P$. lutea at day 1 of exposure (Fig. 5a) even though the temperature increase

289 was higher, with a maximum of $8^{\circ} \mathrm{C}$ above ambient temperature on day 3 . This indicates

290 that even a small increase in temperature can affect $P$. lutea initially, but that they are

291 able to "maintain" their physiological status (GP/R ratios indicating maintained

292 autotrophy) over the temperature range tested in the present study. Although all heat-

293 treated Porites showed a relative decrease in GP/R ratio compared to the corresponding

294 controls, anthropogenic disturbances (e.g. land run-off, sedimentation) seem not to affect

295 their thermotolerance during heat stress. One possible explanation of this could be a more

296 rapid induction of cellular defence mechanisms (e.g. HSP 70 - see Brown, 1997) in these

297 chronically exposed specimens, something that has been demonstrated in marine mussels

298 exposed to heavy metal pollution followed by thermal stress (Veldhuizen-Tsoerkan et al.,

299 1990).

300 Another explanation could be that the coral clades differ between P. lutea and $G$.

301 fascicularis and/or differ between the two areas, since it has been shown that different

302 corals may host different clades of Symbiodinium (LaJeunesse, 2002) and clades can also

303 differ between regions (Baker and Rowan, 1997; Garren et al., 2006). G. fascicularis

304 have been found to harbour both clade C and D (LaJeunesse et al., 2004; Done et al., 

2009), while P. lutea is only hosted by clade C (Chen et al., 2005; Apprill et al., 2007;

306 Hennige et al., 2010), which generally is not associated with corals located in areas 307 exposed to high temperatures (e.g. Baker et al., 2004). Since no analyses of the clades

308 were conducted in this study, further research comparing clades between nearshore and

309 offshore reefs in the area would be of scientific interest. A further explanation to the

310 different responses between the two species and areas could be that the coral hosts are

311 genetically adapted to the local environmental conditions on these reefs, since the

312 environmental quality do differ between nearshore- and offshore reefs, although the

313 thermal history are identical between the areas in the study presented here.

314 Reduction of GP/R ratio has been recognized as a common stress response in

315 corals when exposed to elevated seawater temperature (Coles and Jokiel, 1977; Hoegh-

316 Guldberg and Smith, 1989; Fitt and Warner, 1995; Porter et al., 1999). The observed

317 decrease in GP/R ratio for both P. lutea and G. fascicularis was primarily a result of an

318 increase in respiration rate, which has been demonstrated by other authors (Hoegh-

319 Guldberg and Smith, 1989; Faxneld et al., 2010). However, for nearshore G. fascicularis

320 on day 3 the decrease in GP/R ratio was also explained by a decrease in primary

321 production rates, which also has been shown by other authors (Fitt and Warner, 1995;

322 Porter et al., 1999; Nyström et al., 2001). The higher respiration- and production rates,

323 observed for offshore G. fascicularis, controls and heat-treated, is likely to be attributed

324 to the fact that the offshore colonies were generally smaller - presumably younger

325 colonies - that do have higher metabolic activity.

326 None of the coral species showed signs of bleaching in our study, which supports

327 others studies showing that both G. fascicularis (Marshall and Baird, 2000; McClanahan 
328 et al., 2004) and P. lutea (e.g. Riegl, 1999; Loya et al., 2001; Obura, 2001) are relatively

329 tolerant to elevated seawater temperatures, and suggests that the corals in the present

330 study were not exposed to lethal temperatures, although an increase by $2-3{ }^{\circ} \mathrm{C}$ in 4 hours

331 is in the upper range of what can be expected on shallow reefs in the study area.

332 It should be emphasized that of the temperatures tested here, the 27.5 and $30.5^{\circ} \mathrm{C}$

333 treatments are well below the thermotolerance threshold for most coral species and only

334 the $33.5^{\circ} \mathrm{C}$ treatment is above the normal summer maximum.

\section{5. Conclusion}

338 This study shows that the response of corals to elevated seawater temperature varies with

339 species and environmental background history. The study suggests that the physiological

340 response in G. fascicularis was more pronounced in more disturbed nearshore areas

341 compared to their conspecifics from less disturbed environments, thus supporting the

342 hypothesis that corals in stressful environments (e.g. subjected to land-based pollution

343 and sedimentation) are less tolerant to elevated water temperature. An explanation for this

344 could be that nearshore corals are already closer to their physiological tolerance limit and

345 therefore more sensitive to additional disturbances (Paine et al., 1998). On the other hand,

346 the acclimatory ability may very well differ between coral species. For example, $P$. lutea

347 from nearshore reefs were not more physiologically affected by the temperature increase

348 than corals from offshore reefs. Consequently, it is difficult to predict general effects on

349 coral reefs if episodes of elevated seawater temperatures become more frequent in the

350 future, since these effects may be area and species specific. One likely consequence, 
351 however, is that due to differences in acclimatory capability among coral species, reefs

352 may suffer losses in biodiversity (Loya et al., 2001), which in turn may impact the

353 resilience of coral reefs (Nyström et al., 2000; Bellwood et al., 2004).

354

355 Acknowledgements

356 This work is supported by Sida/SAREC, and we also thank Stockholm Marine Research

357 Center (SMF) for providing financial support. We are grateful to Dr. $\mathrm{Cu}$ for allowing us

358 to use his facilities for conducting this experiment and all the helpful staff at Tram Bien

359 Research Station. We also thank the anonymous reviewers for their pertinent and helpful 360 comments.

361

362 List of figures

364 Fig 1. Map showing the collection sites. The nearshore, more disturbed reefs (Ba Trai

365 Dao and Van Boi) are situated in the north and the offshore less disturbed reefs (Vung

366 Tau and Vung Cay Bang) $20 \mathrm{~km}$ to the south.

368 Fig 2. a) Monthly averages of chlorophyll $\alpha$ concentrations (a proxy for water clarity)

369 from September 1997 to August 2010. The solid line shows the nearshore area and the

370 dotted line shows the offshore area.

371 b) Monthly averages of temperature $\left({ }^{\circ} \mathrm{C}\right)$ from July 2002 to July 2010 . The solid line is

372 showing data for both the nearshore and the offshore areas, since the average

373 temperatures were identical. 
374 The data were acquired from the Giovanni online data system

375 (http://gdata1.sci.gsfc.nasa.gov/daac-bin/G3/gui.cgi?instance_id=ocean_month;

376 downloaded 1 November 2010), which was developed and is maintained by the NASA

377 Goddard Earth Sciences (GES) Data and Information Services Center (DISC).

378

379 Fig 3. Galaxea fascicularis. GP/R ratio \pm SE. a) Nearshore corals a) Offshore corals. The

380 dark bars show the controls (exposed to $25.5^{\circ} \mathrm{C}$ during the whole study) and the light

381 bars are the heat-exposed corals (heat-exposure: day $1=27.5^{\circ} \mathrm{C}$, day $2=30.5^{\circ} \mathrm{C}$, day

$3823=33.5^{\circ} \mathrm{C}$, day $\left.4=25.5^{\circ} \mathrm{C}\right) .{ }^{*} \mathrm{p}<0.05$.

383

384 Fig 4. Galaxea fascicularis. Polyp extension. a) Nearshore corals b) Offshore corals when 385 exposed to $33.5^{\circ} \mathrm{C}$ on day 3 .

387 Fig 5. Porites lutea. GP/R ratio \pm SE. a) Nearshore corals b) Offshore corals. The dark 388 bars show the controls (exposed to $25.5^{\circ} \mathrm{C}$ during the whole study) and the light bars are

389 the heat-exposed corals (heat-exposure: day $1=27.5^{\circ} \mathrm{C}$, day $2=30.5^{\circ} \mathrm{C}$, day $3=33.5^{\circ} \mathrm{C}$, 390 day $\left.4=25.5^{\circ} \mathrm{C}\right) .{ }^{*} \mathrm{p}<0.05$.

391

392 List of tables

393

394 Table 1. Environmental data from the offshore (Long Chau Islands) and the nearshore

395 (Cat Ba) sites used in this study. Data from biannual surveys provided by The Institute of

396 Marine Environment and Resources, Hai Phong, Vietnam. 
398 Table 2. Galaxea fascicularis. Results from the ANOVA where all nearshore and

399 offshore corals have been compared to the controls. P-values $<0.05$ demonstrate

400 significant differences between heat-treated and controls. + depicts cases when Kruskal-

401 Wallis was used.

402

403 Table 3. Galaxea fascicularis. Mean \pm SE for heat-treated and controls from nearshore

404 and offshore reefs. a) Respiration rates b) Gross primary production rates.

405

406 Table 4. Porites lutea. Results from the ANOVA where all nearshore and offshore corals

407 have been compared to the controls. P-values $<0.05$ demonstrate significant differences

408 between heat-treated and controls.

409

410 Table 5. Porites lutea. Mean \pm SE for heat-treated and controls from nearshore and

411 offshore reefs. a) Respiration rates b) Gross primary production rates. $* * \mathrm{p}<0.01$.

412

413 


\section{References}

415 Apprill, A.M., Bidigare, R.R., Gates, R.D., 2007. Visibly healthy corals exhibit variable pigment

416 concentrations and symbiont phenotypes. Coral reefs 26, 387-397

417 Baker, A.C., Rowan, R., 1997. Diversity of symbiotic dinoflagellates (zooxanthellae) in scleractinian corals

418 of the Caribbean and Eastern Pacific. Proceedings of $8^{\text {th }}$ International Coral Reef Symposium 2, 1301-1306

419 Baker, A.C., Starger, C., McClanahan, T.R., Glynn, P.W., 2004. Coral's adaptive response to climate

420 change. Nature 430, 741

421 Bellwood, D.R., Hughes, T.P., Folke, C., Nyström, M., 2004. Confronting the coral reef crisis. Nature 429,

$422 \quad 827-833$

423 Brown, B.E., 1997. Adaptations of reef corals to physical environmental stress. Advances in Marine

424 Biology 31, 221-299

425 Brown, B.E., Le Tissier, M.D.A., Dunne, R.P., 1994. Tissue retraction in the scleractinian coral Coeloseris

426 mayeri, its effect upon coral pigmentation, and preliminary implications for heat balance. Marine Ecology

427 Progress Series 105, 209-218

428 Bryant, D., Burke, L., McManus, J., Spalding, M., 1998. Reefs at risk: a map-based indicator of threats to 429 the world's coral reefs. World resources institute, Washington DC.

430 Burke, L., Selig, E., Spalding, M., 2002. Reefs at risk in Southeast Asia. World resources institute, 431 Washington DC. p 45.

432 Carilli, J.E., Norris, R.D., Black, B.A., Walsh, S.M., McField, M., 2009. Local stressors reduce coral 433 resilience to bleaching. PLOS One 4, 1-5

434 Chen, C.A., Yang Y-W., Wei, N.V., Tsai, W-S., Fang L-S., 2005. Symbiont diversity in scleractinian corals 435 from tropical and subtropical non-reef communities in Taiwan. Coral Reefs 24, 11-22

436 Chou, L.M., Tuan, V.S., Philreefs, Yeemin, T., Cabanban, A., Suharsono, Kessna, I., 2002. Status of 437 Southeast Asian reefs. In: Wilkinson, C.P. (Ed.), Coral reefs of the world: 2002. Australian institute of 438 marine science. Townsville, Queensland, Australia, pp 123-152.

439 Coles, S.L., Jokiel, P.L., 1977. Effects of temperature on photosynthesis and respiration in hermatypic 440 corals. Marine Biology 43, 209-216 
441 Coyer, J.A., Ambrose, R.F., Engle, J.M., Carroll, J.C., 1993. Interactions between corals and algae on a

442 temperate zone rocky reef: mediation by sea urchins. Journal of Experimental Marine Biology and Ecology

$443 \quad 167,21-37$

444 Crabbe, M.J.C., Smith, D.J., 2005. Sediment impacts on growth rates of Acropora and Porites from

445 fringing reefs of Sulawesi, Indonesia. Coral reefs 24, 437-441

446 Craig, P., Birkeland, C., Belliveau, S., 2001. High temperatures tolerated by a diverse assemblage of 447 shallow-water corals in American Samoa. Coral reefs 20, 185-189

448 Diaz-Pulido, G., McCook, L.J., 2002. The fate of bleached corals: patterns and dynamics of algal 449 recruitment. Marine Ecology Progress Series 232, 115-128

450 Dong, Z-J., Huang, H., Huang, L-M., Li, Y-C., 2009. Diversity of symbiotic algae of the genus 451 Symbiodinium in scleractinian corals of the Xisha Islands in the South China Sea. Journal of Systematics 452 and Evolution 47, 321-326

453 Donner, S.D., Skirving, W.J., Little, C.M., Oppenheimer, M., Hoegh-Guldberg, O., 2005. Global 454 assessment of coral bleaching and required rates of adaptation under climate change. Global Change 455 Biology 11, 2251-2265

456 Douglas, A.E., 2003. Coral bleaching-how and why? Marine Pollution Bulletin 46, 385-392

457 Edwards, A.J., Clark, S., Zahir, H., Rajasuriya, A., Naseer, A., Rubens, J., 2001. Coral bleaching and 458 mortality on artificial and natural reefs in Maldives in 1998, sea surface temperature anomalies and initial 459 recovery. Marine Pollution Bulletin 42, 7-15

460 Fabricius, K.E., 2005. Effects of terrestrial runoff on the ecology of corals and coral reefs: review and 461 synthesis. Marine Pollution Bulletin 50, 125-146

462 Faxneld, S., Jörgensen, T.L., Tedengren, M., 2010. Effects of elevated water temperature, reduced salinity 463 and nutrient enrichment on the metabolism of the coral Turbinaria mesenterina. Estuarine, coastal and shelf 464 science $88,482-487$

465 Fitt, W.K., Warner, M.E., 1995. Bleaching patterns in four species of Caribbean reef corals. Biological 466 Bulletin 189, 298-307 

to between geographic regions. Coral reefs $25,503-512$

470 Glynn, P.W., 1996. Coral reef bleaching: facts, hypotheses and implications. Global change biology 2, 495$471 \quad 509$

472 Glynn, P.W., Maté, J.L., Baker, A.C., Calderón, O., 2001. Coral bleaching and mortality in Panama and 473 Ecuador during the 1997-1998 El Nino-Southern Oscillation event: spatial/temporal patterns and comparisons with the 1992-1993 event. Bulletin of Marine Science 9, 79-109

475 Hennige, S.J., Smith, D.J., Walsh, S-J., McGinley, M.P., Warner, M.E., Suggett D.J., 2010. Acclimation 476 and adaptation of scleractinian coral communities along environmental gradients within an Indonesian reef system. Journal of Experimental Marine Biology and Ecology 391, 143-152

478 Hoegh-Guldberg, O., 1999. Climate change, coral bleaching and the future of the world's coral reefs.

479 Marine and Freshwater Research 50, 839-866

480 Hoegh-Guldberg, O., Mumby, P.J., Hooten, A.J., Steneck, R.S., Greenfield, P., Gomez, E., Harvell, C.D., 481 Sale, P.F., Edwards, A.J., Caldeira, K., Knowlton, N., Eakin, C.M., Iglesis-Prieto, R., Muthiga, N., 482 Bradbury, R.H., Dubi, A., Hatziolos, M.E., 2007. Coral reefs under rapid climate change and ocean 483 acidification. Science 318, 1737-1742

484 Hoegh-Guldberg, O., Smith, J.G., 1989. The effect of sudden changes in temperature, light and salinity on 485 the population density and export of zooxanthellae from the reef corals Stylophora pistillata Esper and 486 Seriatopora hystrix Dana. Journal of Experimental Marine Biology and Ecology 129, 279-303

487 Hughes, T.P., Baird, A.H., Bellwood, D.R., Card, M., Connolly, S.R., Folke, C., Grosberg, R., Hoegh-

488 Guldberg, O., Jackson, J.B.C., Kleypas, J., Lough, J.M., Marshall, P., Nyström, M., Palumbi, S.R.,

489 Pandolfi, J.M., Rosen, B., Roughgarden, J., 2003. Climate change, human impacts, and the resilience of 490 coral reefs. Science 301, 929-933

491 IPCC., 2007. Climate Change 2007: The physical science basis. Contribution of working group 1 to the 492 fourth assessment report of the intergovernmental panel on climate change. Solomon, S., Qin, M., 493 Manning, M., Chen, Z., Marquis, M., Averyt, K.B., Tignor, M., Miller, H.L. (Eds.), Cambridge Univ Press, 494 Cambridge, United Kingdom and New York, NY, USA 
495 Jones, R.J., Ward, S., Amri, A.Y., Hoegh-Guldberg, O., 2000. Changes in quantum efficiency of

496 Photosystem II of symbiotic dinoflagellates of corals after heat stress, and of bleached corals sampled after

497 the 1998 Great Barrier Reef mass bleaching event. Marine and Freshwater Research 51, 63-71

498 Jupiter, S., Roff, G., Marion, G., Henderson, M., Schrameyer, V., McCulloch, M., Hoegh-Guldberg, O.,

499 2008. Linkages between coral assemblages and coral proxies of terrestrial exposure along a cross-shelf

500 gradient on the southern Great Barrier Reef. Coral Reefs 27, 887-903

501 LaJeunesse, T.C., 2002. Diversity and community structure of symbiotic dinoflagellates from Caribbean

502 coral reefs. Marine Biology 141, 387-400

503 LaJeunesse, T.C., Bhagooli, R., Hidaka, M., de Vantier, L., Done, T., Schmidt, G.W., Fitt, W.K., Hoegh-

504 Guldberg, O., 2004. Closely related Symbiodinium spp. differ in relative dominance in coral reef host

505 communities across environmental, latitudinal and biogeographic gradients. Marine Ecology Progress

506 Series 284, 147-161

507 LaJeunesse, T.C., Pettay, D.T., Sampayo, E.M., Phongsuwan, N., Brown, B., Obura, D.O., Hoegh-

508 Guldberg, O., Fitt, W.K., 2010a. Long-standing environmental conditions, geographic isolation and host-

509 symbiont specificity influence the relative ecological dominance and genetic diversification of coral

510 endosymbionts in the genus Symbiodinium. Journal of biogeography 37, 785-800

511 LaJeunesse, T.C., Smith, R., Walther, M., Pinzón, J., Pettay, D.T., McGinley, M., Aschaffenburg, M.,

512 Medina-Rosas, P., Cupul-Magaña, A.L., López Pérez, A., Reyes-Bonilla, H., Warner, M.E., 2010b. Host-

513 symbiont recombination versus natural selection in the response of coral-dinoflagellate symbioses to

514 environmental disturbance. Proceedings of the Royal Society B 277, 2925-2934

515 Lambo, A.L., Ormond, R.F.G., 2006. Continued post-bleaching decline and changed benthic community of

516 a Kenyan coral reef. Marine Pollution Bulletin 52, 1617-1624

517 Lang, V.K., Dam, D.T., Dautova, T.N., Latypov, Y.Y., 2004. Sedimentation and water exchange on coral

518 reefs in the Ha Long - Cat Ba area, Quang Ninh Province, North Viet Nam. In: Thanh, T.D. (Ed.), Marine

519 resources and environment, TOME XI. Vietnamese academy of science and technology, Institute of Marine

520 environment and resources, Haiphong, Vietnam, pp 181-193

521 Latypov, Y.Y., 2005. Reef-building corals of Vietnam as a part of the Indo-Pacific reef ecosystem. Russian

522 journal of marine biology $31, \mathrm{~s} 34-\mathrm{s} 40$ 
523 Loya, Y., Sakai, K., Yamazato, K., Nakano, Y., Sambali, H., van Woesik, R., 2001. Coral bleaching: the

524 winners and the losers. Ecology Letters 4, 122-131

525 March, J.A., 1970. Primary productivity of reef-building calcareous red algae. Ecology 51, 255-263

526 Marshall, P.A., Baird, A.H., 2000. Bleaching of corals on the Great Barrier Reef: differential

527 susceptibilities among taxa. Coral Reefs 19, 155-163

528 McClanahan, T.R., 2000. Bleaching damage and recovery potential of Maldivian coral reefs. Marine

529 Pollution Bulletin 40, 587-597

530 McClanahan, T.R., 2004. The relationship between bleaching and mortality of common corals. Marine

531 Biology 144:1239-1245

532 McClanahan, T.R., Ateweberhan, M., Graham, N.A.J., Wilson, S.K., Ruiz Sebastián, C., Guillaume, M.M.,

533 Bruggemann, J.H., 2007. Western Indian Ocean coral communities: bleaching responses and susceptibility

534 to extinction. Marine Ecology Progress Series 337, 1-13

535 McClanahan, T.R., Baird, A.H., Marshall, P.A., Toscano, M.A., 2004. Comparing bleaching and mortality

536 responses of hard corals between southern Kenya and the Great Barrier Reef, Australia. Marine Pollution

537 Bulletin 48, 327-335

538 McClanahan, T.R., Maina, J., Moothien-Pillay, R., Baker, A.C., 2005. Effects of geography, taxa, water

539 flow, and temperature variation on coral bleaching intensity in Mauritius. Marine Ecology Progress Series

$540 \quad 298,131-142$

541 Moberg, F., Nyström, M., Kautsky, N., Tedengren, M., Jarayabhand, P., 1997. Effects of reduced salinity

542 on the rates of photosynthesis and respiration in the hermatypic corals Porites lutea and Pocillopora

543 damicornis. Marine Ecology Progress Series 157, 53-59

544 Mora, C., 2008. A clear human footprint in the coral reefs of the Caribbean. Proceedings of the Royal

545 Society B $275,767-773$

546 Muscatine, L., 1990. The role of symbiotic algae in carbon and energy flux in reef corals. In: Dubinsky, Z.

547 (Ed.), Ecosystems of the world 25: Coral reefs. Elsevier, Amsterdam Oxford New York Tokyo, pp 75-87

548 Nordemar, I., Nyström, M., Dizon, R., 2003. Effects of elevated seawater temperature and nitrate

549 enrichment on the branching coral Porites cylindrica in the absence of particulate food. Marine Biology

$550 \quad 142,669-677$ 
551 Nyström, M., Folke, C., Moberg, F., 2000. Coral reef disturbances and resilience in a human-dominated

552 environment. Trends in Ecology and Evolution 15, 413-417

553 Nyström, M., Nordemar, I., Tedengren, M., 2001. Simultaneous and sequential stress from increased

554 temperature and copper on the metabolism of the hermatypic coral Porites cylindrica. Marine Biology 138,

$555 \quad 1225-1231$

556 Obura, D.O., 2001. Can differential bleaching and mortality among coral species offer useful indicators for 557 assessment and management of reefs under stress? Bulletin of Marine Science 69, 421-442

558 Paine, R.T., Tegner, M.J., Johnson, E.A., 1998. Compounded perturbations yield ecological surprises.

559 Ecosystems 1, 535-545

560 Pandolfi, J.M., Jackson, J.B.C., Baron, N., Bradbury, R.H., Guzman, H.M., Hughes, T.P., Kappel, C.V.,

561 Michell, F., Ogden, J.C., Possingham, H.P., Sala, E., 2007. Are U.S. coral reefs on the slippery slope to

562 slime? Science 307, 1725-1726

563 Porter, J.W., Lewis, S.K., Porter, K.G., 1999. The effects of multiple stressors on the Florida Keys coral 564 reef ecosystem: a landscape hypothesis and a physiological test. Limnology and Oceanography 44, 941-949

565 Riegl, B., 1999. Corals in a non-reef setting in the southern Arabian Gulf (Dubai, UAE): fauna and 566 community structure in response to recurring mass mortality. Coral Reefs 18, 63-73

567 Rogers, C.S., 1990. Responses of coral reefs and reef organisms to sedimentation. Marine Ecology Progress

568 Series $62,185-202$

569 Rowan, R., 2004. Thermal adaptation in reef coral symbionts. Nature 430, 742

570 Semesi, I.S., Kangwe, J., Björk, M., 2009. Alterations in seawater $\mathrm{pH}$ and $\mathrm{CO}_{2}$ affect calcification and 571 photosynthesis in tropical coralline alga, Hydrolithon sp. (Rhodophyta). Estuarine, Coastal and Shelf

572 Science 84, 337-341

573 Sheppard, C., Rioja-Nieto, R., 2005. Sea surface temperature 1871-2099 in 38 cells in the Caribbean

574 region. Marine Environmental Research 60, 389-396

575 Spencer, T., Teleki, K.A., Bradshaw, C., Spalding, M.D., 2000. Coral bleaching in the Southern Seychelles 576 during the 1997-1998 Indian Ocean warm event. Marine Pollution Bulletin 40, 569-586

577 Tran, D.T., Tran, D.L., Dang, H.N., Nguyen, T.K.A., 2004. An overview of the geological values and

578 sedimentary environment of Ha Long Bay. In: Tran, D.T. (Ed.), Marine resources and environment, TOME 
579 XI. Vietnamese academy of science and technology, Institute of Marine environment and resources,

580 Haiphong, Vietnam, pp 38-64

581 Tuan, V.S., 2000. Reports on status of coral reefs in Vietnam: 2000. Proceedings of 9th International Coral

582 Reef Symposium 2, 891-894

583 Ulstrup, K.E., Berkelmans, R., Ralph, P.J., van Oppen, M.J.H., 2006. Variation in bleaching sensitivity of

584 two coral species across a latitudinal gradient on the Great Barrier Reef: the role of zooxanthellae. Marine

585 Ecology Progress Series 314, 135-148

586 Veldhuizen-Tsoerkan, M.B., Holwerda, D.A., van der Mast, C.A., Zandee, D.I., 1990. Effects of Cadmium

587 exposure and heat shock on protein synthesis in gill tissue of the sea mussel Mytilus edulis L. Comparative

588 Biochemistry and Physiology 96C, 419-426

589 Warner, M.E., Fitt, W.K., Schmidt, G.W., 1999. Damage to photosystem II in symbiotic dinoflagellates: a

590 determinant of coral bleaching. Proceedings of the National Academy of Sciences of the United States of

591 America. 96, 8007-8012

592 Wilkinson, C.P. (Ed.), 2004. Status of coral reefs of the world: 2004. Australian Institute of Marine

593 Science, Townsville, Queensland, Australia.

594 Wilkinson, C.P. (Ed.), 2006. Status of coral reefs of the world: 2006. Australian Institute of Marine

595 Science, Townsville, Queensland, Australia.

596 Wood, R., 1995. The changing biology of reef-building. Palaios 10, 517-529 
Chronically disturbed Galaxea fascicularis respond negatively to temperature increase

Porites lutea not more affected by elevated temperature when chronically stressed

Temperature increase affects even coral species from the same area differently 


\section{List of tables}

Table 1

\begin{tabular}{|c|c|c|c|c|}
\hline & Offshore & & Nearshore & \\
\hline Average (year 2005-2008, $n=4$ ) & Dry season $^{a}$ & Rainy season ${ }^{b}$ & Dry season $^{a}$ & Rainy season ${ }^{b}$ \\
\hline Salinity (psu) & 32 & 26 & 32 & \\
\hline pH & 8.13 & 8.34 & 8.09 & 8.32 \\
\hline Sedimentation $\left(\mathrm{g} \mathrm{m}^{-2 *} \mathrm{day}^{-1}\right)$ & $1.99 \pm 0.39$ & $0.38 \pm 0.17$ & $3.42 \pm 0.14$ & $4.19 \pm 0.21$ \\
\hline Visibility $(\mathrm{m})$ & 3.0 & 3.0 & 5.5 & 4.0 \\
\hline Nitrate* $\left(\mu g^{*} 1^{-1}\right)$ & $86.2 \pm 2.5$ & & $135.5 \pm 11.8$ & \\
\hline
\end{tabular}

Numbers show mean \pm SD. ${ }^{a}$ The dry season lasts from October to May, ${ }^{b}$ the rainy season lasts from June to September, * average of 2 measurements March-May 2003.

Table 2

\begin{tabular}{|l|cccc}
\hline & Day & df & $\mathbf{F}$ & $\mathbf{P}$ \\
\hline GP/R & 1 & 3 & $4.835+$ & 0.184 \\
& 2 & 3 & 8.677 & $\mathbf{0 . 0 0 0}$ \\
& 3 & 3 & $15.417+$ & $\mathbf{0 . 0 0 1}$ \\
$\mathbf{R}$ & 4 & 3 & $8.305+$ & $\mathbf{0 . 0 4 0}$ \\
& 1 & 3 & 7.947 & $\mathbf{0 . 0 0 1}$ \\
& 2 & 3 & 21.149 & $\mathbf{0 . 0 0 0}$ \\
$\mathbf{G P}$ & 3 & 3 & $22.454+$ & $\mathbf{0 . 0 0 0}$ \\
& 4 & 3 & 11.150 & $\mathbf{0 . 0 0 0}$ \\
& 1 & 3 & 4.459 & $\mathbf{0 . 0 1 2}$ \\
& 2 & 3 & 7.812 & $\mathbf{0 . 0 0 1}$ \\
& 3 & 3 & 6.357 & $\mathbf{0 . 0 0 2}$ \\
& 4 & 3 & 6.354 & $\mathbf{0 . 0 0 2}$ \\
\hline
\end{tabular}

Table 3a

\begin{tabular}{|lllll|}
\hline & \multicolumn{2}{c}{ Nearshore } & \multicolumn{2}{c|}{ Offshore } \\
\hline Respiration & Control & Heat-treated & Control & Heat-treated \\
\hline & & & & \\
Day 1 & $5.21 \pm 1.47$ & $7.88 \pm 0.35$ & $11.95 \pm 1.30$ & $17.0 \pm 2.15$ \\
Day 2 & $4.44 \pm 1.29$ & $7.16 \pm 0.56$ & $11.49 \pm 1.13$ & $20.3 \pm 2.21$ \\
Day 3 & $2.78 \pm 1.25$ & $8.85 \pm 1.42$ & $8.29 \pm 0.76$ & $21.9 \pm 2.10$ \\
Day 4 & $2.06 \pm 0.97$ & $7.68 \pm 0.89$ & $6.06 \pm 1.03$ & $15.7 \pm 2.30$ \\
\hline
\end{tabular}


Table $3 b$

\begin{tabular}{|lllll|}
\hline \multicolumn{2}{c}{ Nearshore } & \multicolumn{2}{c|}{ Offshore } \\
\hline Gross production Control & Heat-treated & Control & Heat-treated \\
\hline & & & & \\
Day 1 & $19.9 \pm 7.35$ & $20.7 \pm 1.93$ & $25.8 \pm 3.02$ & $43.3 \pm 6.34$ \\
Day 2 & $28.2 \pm 18.7$ & $21.5 \pm 2.43$ & $27.1 \pm 3.06$ & $54.9 \pm 6.49$ \\
Day 3 & $29.1 \pm 1.35$ & $15.1 \pm 4.87$ & $34.1 \pm 4.51$ & $59.7 \pm 6.47$ \\
Day 4 & $26.8 \pm 1.00$ & $28.8 \pm 1.99$ & $39.2 \pm 5.91$ & $73.2 \pm 1.05$ \\
\hline
\end{tabular}

Table 4

\begin{tabular}{|l|cccc}
\hline & Day & df & $\mathbf{F}$ & $\mathbf{P}$ \\
\hline $\mathbf{G P / R}$ & 1 & 3 & 6.542 & $\mathbf{0 . 0 0 1}$ \\
& 2 & 3 & 1.469 & 0.243 \\
& 3 & 3 & 6.161 & $\mathbf{0 . 0 0 2}$ \\
$\mathbf{R}$ & 4 & 3 & 1.605 & 0.217 \\
& 1 & 3 & 6.911 & $\mathbf{0 . 0 0 1}$ \\
& 2 & 3 & 4.999 & $\mathbf{0 . 0 0 6}$ \\
& 3 & 3 & 3.666 & $\mathbf{0 . 0 2 3}$ \\
$\mathbf{G P}$ & 4 & 3 & 0.771 & 0.523 \\
& 1 & 3 & 1.536 & 0.224 \\
& 2 & 3 & 2.128 & 0.117 \\
& 3 & 3 & 3.855 & $\mathbf{0 . 0 1 8}$ \\
& 4 & 3 & 0.803 & 0.502 \\
\hline
\end{tabular}

Table 5a

\begin{tabular}{|llcll|}
\hline & \multicolumn{2}{c}{ Nearshore } & \multicolumn{2}{c|}{ Offshore } \\
\hline Respiration & Control & Heat-treated & Control & Heat-treated \\
\hline & & & & \\
Day 1 & $6.29 \pm 0.79$ & $15.9 \pm 2.16 * *$ & $5.99 \pm 0.92$ & $9.61 \pm 2.39$ \\
Day 2 & $5.74 \pm 0.49$ & $14.3 \pm 1.14$ & $6.09 \pm 0.76$ & $7.75 \pm 2.77$ \\
Day 3 & $4.69 \pm 0.98$ & $9.08 \pm 1.56$ & $3.21 \pm 0.79$ & $5.84 \pm 1.50$ \\
Day 4 & $3.63 \pm 0.51$ & $4.81 \pm 1.08$ & $2.29 \pm 0.54$ & $2.94 \pm 0.53$ \\
\hline
\end{tabular}

Table $5 b$

\begin{tabular}{|lllll|}
\hline \multicolumn{2}{|c}{ Nearshore } & \multicolumn{2}{c|}{ Offshore } \\
\hline \multicolumn{2}{|c}{ Gross production Control } & Heat-treated & Control & Heat-treated \\
\hline & & & & \\
Day 1 & $21.7 \pm 3.97$ & $31.3 \pm 4.62$ & $19.9 \pm 2.12$ & $22.6 \pm 4.79$ \\
Day 2 & $24.2 \pm 3.06$ & $41.3 \pm 4.27$ & $23.7 \pm 2.56$ & $26.0 \pm 1.04$ \\
Day 3 & $32.5 \pm 5.31$ & $48.2 \pm 7.12$ & $21.8 \pm 3.15$ & $22.6 \pm 7.85$ \\
Day 4 & $31.9 \pm 4.36$ & $35.8 \pm 5.62$ & $25.8 \pm 2.48$ & $25.7 \pm 7.88$ \\
\hline
\end{tabular}




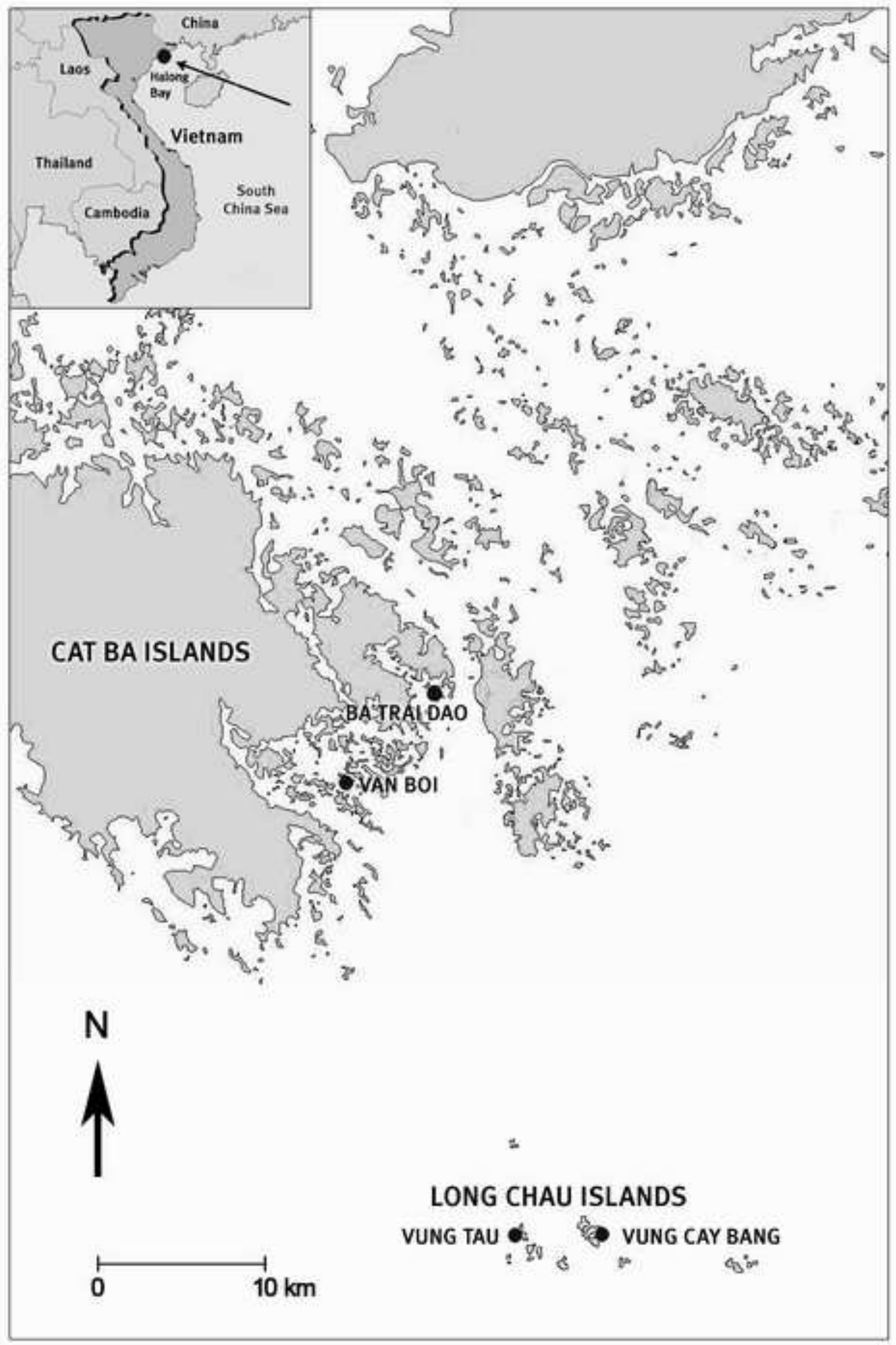


Figure 2a

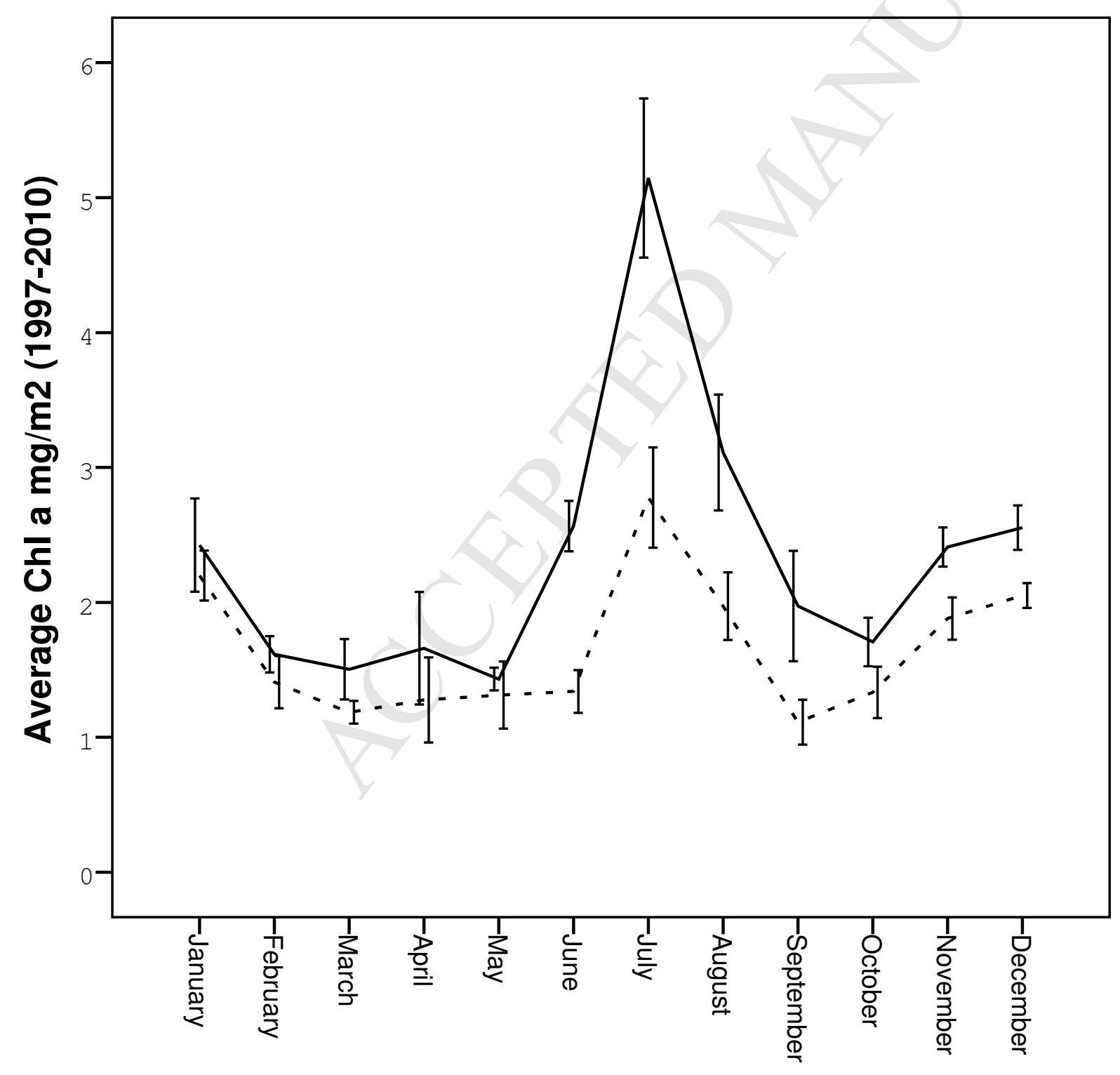


Figure 2b

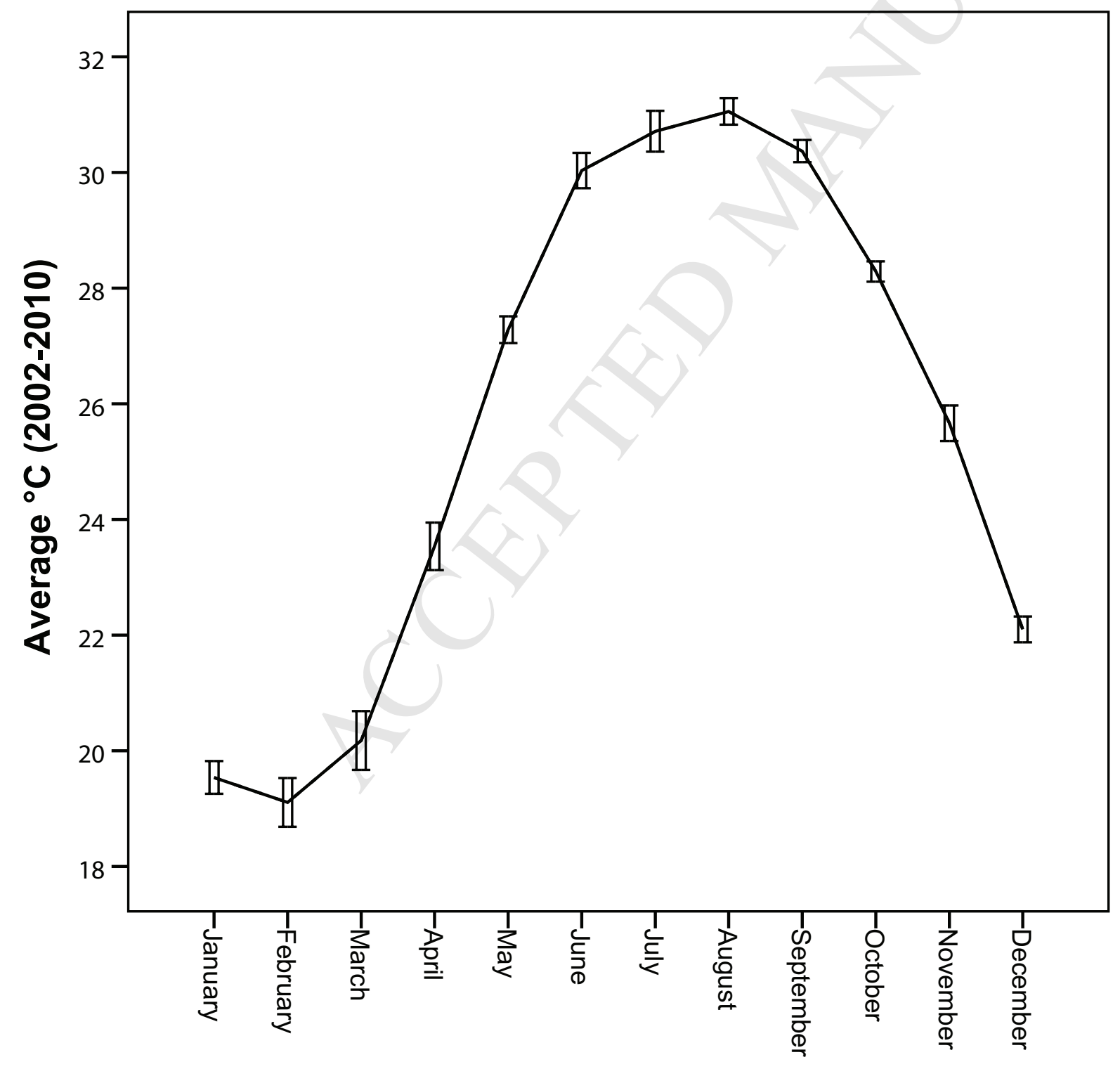



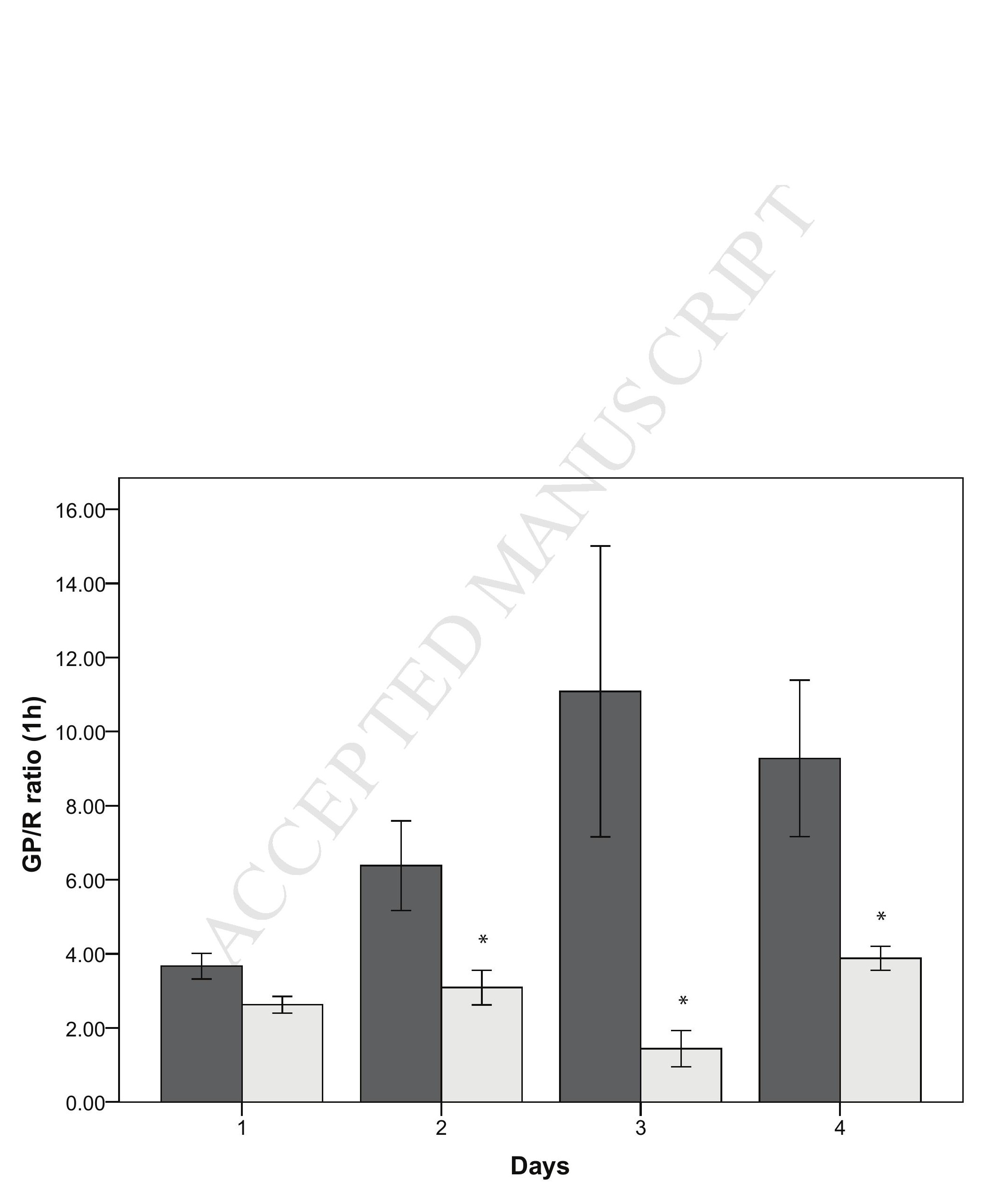


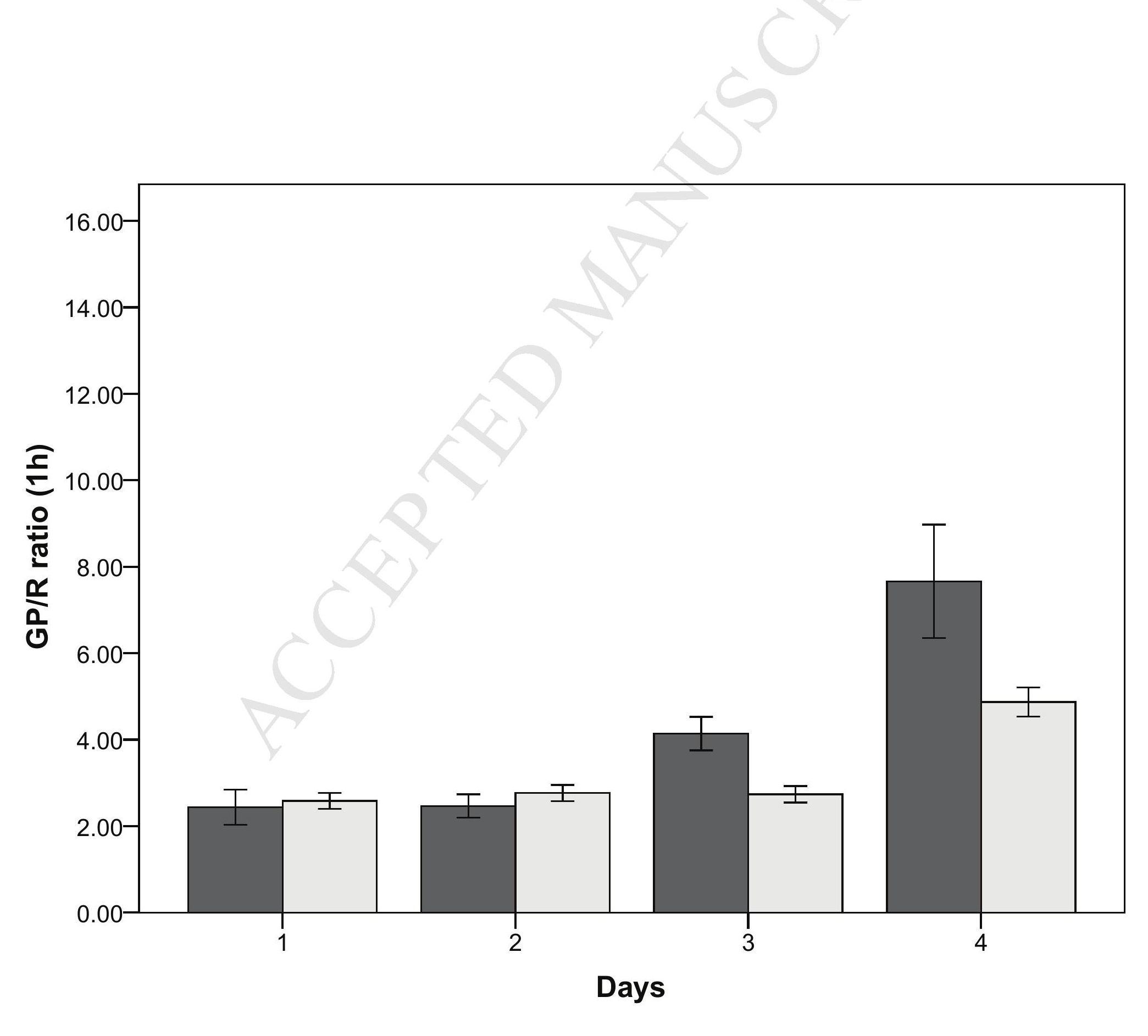

Figure 3b 


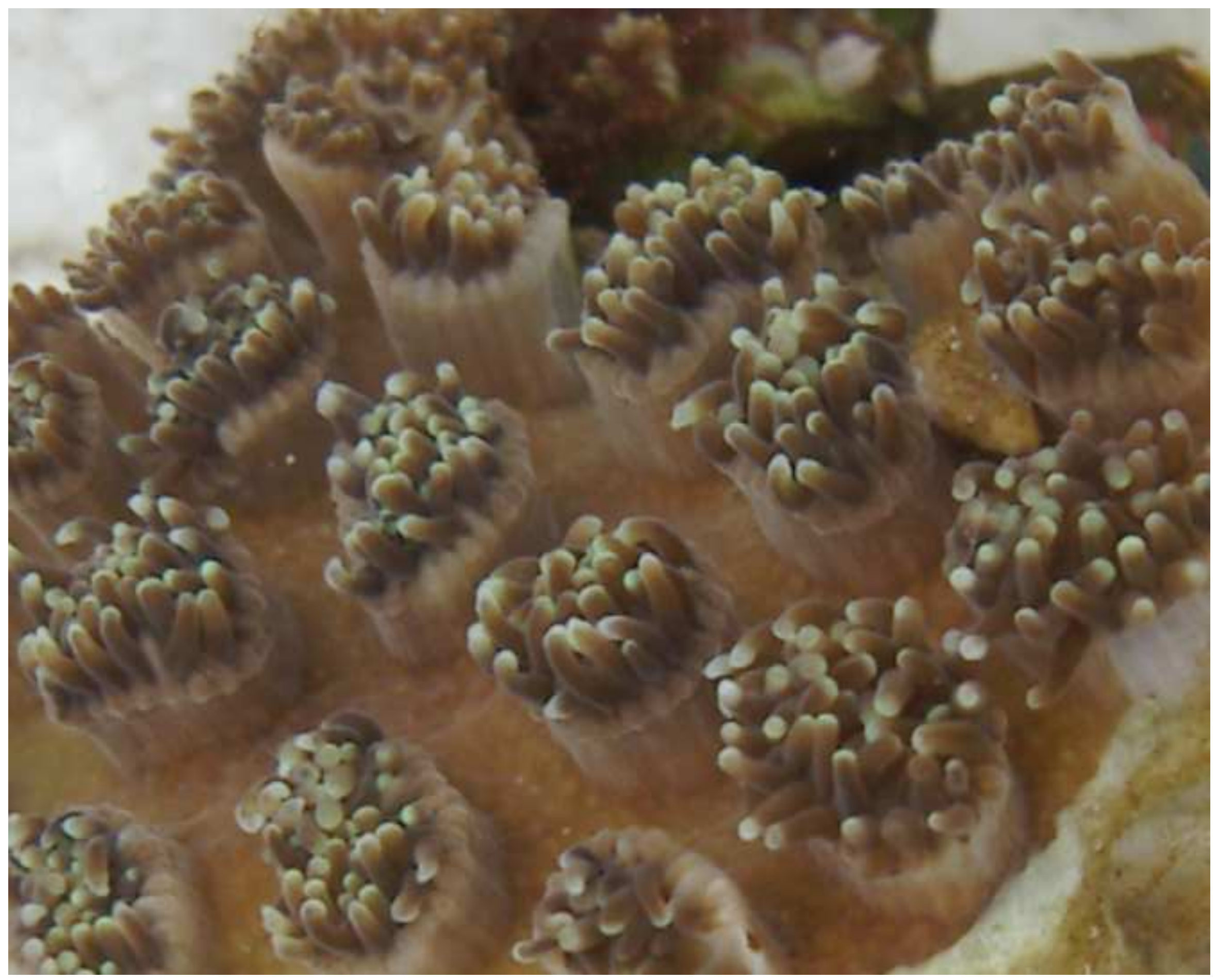


Figure $4 \mathrm{~b}$
Click here to download high resolution image

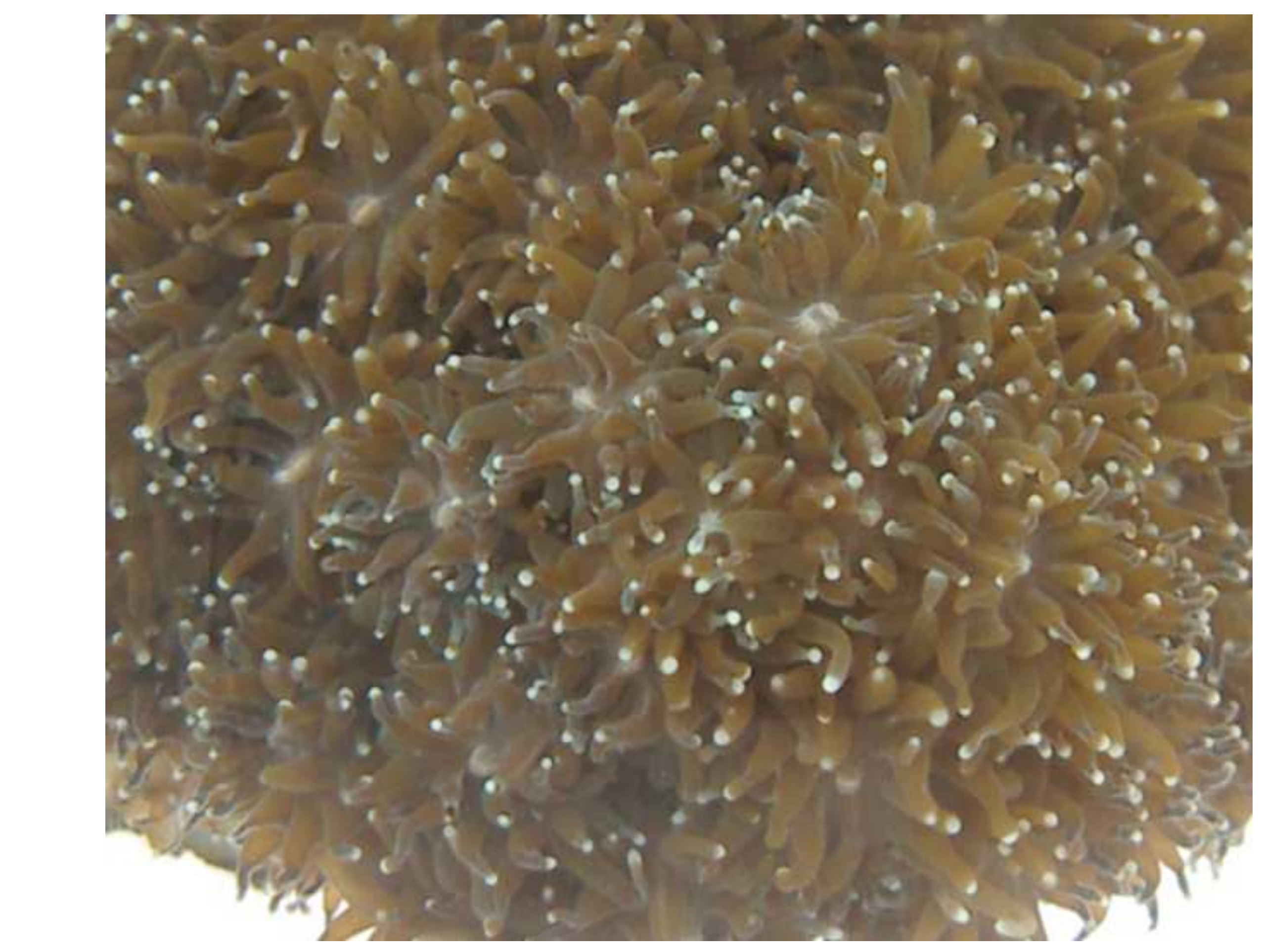



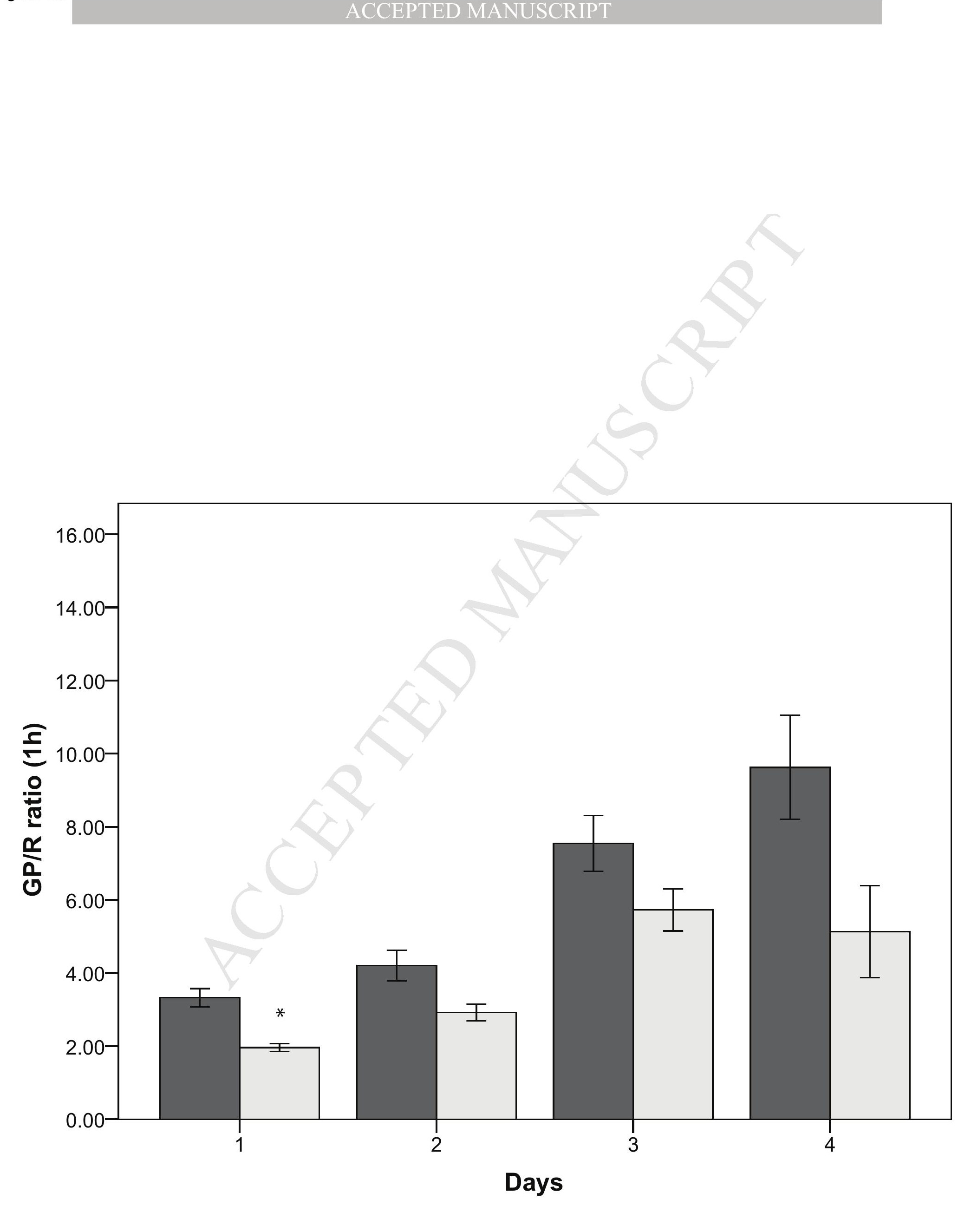


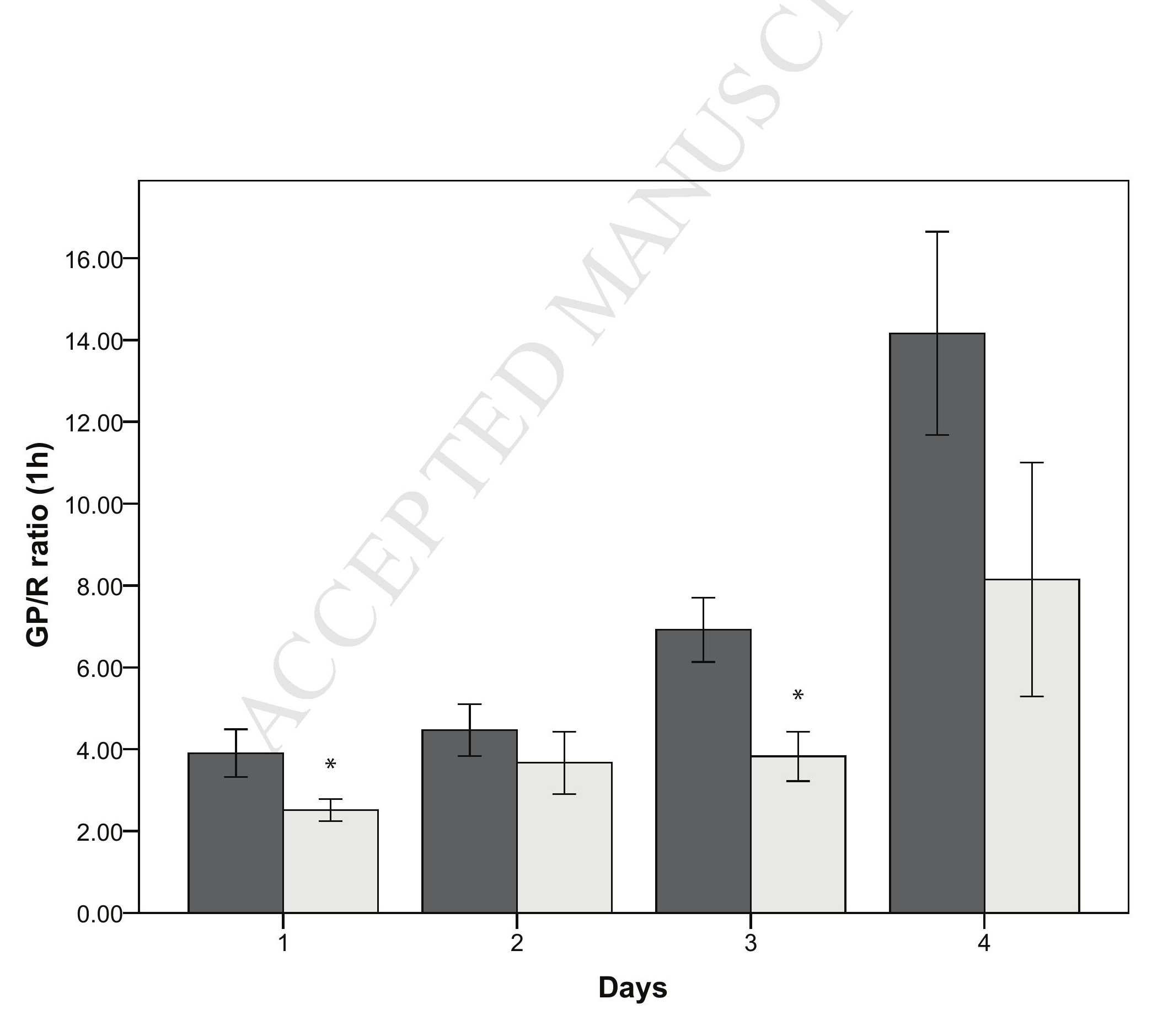

ACCEPTED MANUSCRIPT 